\title{
Medicinal Plants Diversity in Traditional Treatment of Rejang Ethnic Communities in Rejang Lebong Regency as a Resource for Learning Plant Taxonomy
}

\author{
Kasrina Kasrina ${ }^{*}$, Alif Yanuar Zukmadini, Febri Ade Bunga Laily, Selvia Rahmi
}

Biology Education Study Program, University of Bengkulu

*Corresponding author. Email: kasrina@unib.ac.id

\begin{abstract}
The Rejang ethnic is one of the largest ethnics in Bengkulu Province, generally domiciled in Rejang Lebong Regency, Lebong. One of the local wisdoms of this tribal community until now is to practice traditional medicine as a cultural heritage, but most of it is passed on to the next generation by oral tradition, thus allowing this knowledge to be reduced from generation to generation and not well documented. For this reason, exploration and documentation of medicinal plants are needed so that the traditional healing culture is not lost. Documentation in writing is indispensable for the development of traditional medicine in the future and to be integrated in learning as a source of teaching materials based on local wisdom to bring back cultural values for future generations. This research aims to study the diversity of plants used in traditional disease treatment by The Rejang ethnic, their conservation, and identification of the dominant family taxon groups were selected as learning sources. The research was conducted in Pasar Tengah Sub-District, Teladan, Air Pikat Village, Rejang Lebong Regency, using observation, and interview methods on Bahtera and selected informants by purposive sampling. The results of the study found 101 species, 50 families of medicinal plants that can treat 90 kinds of diseases traditionally such as malaria, cancer, stomachache, skin diseases, diarrhea, fever and others. Medicinal plants are generally planted in the yard. The dominant taxon families with the number of species (sp) are: Zingiberaceae (8sp), Euphorbiaceae (7sp), Fabaceae (6sp), Achantaceae (6sp) Solanaceae (5sp), Lamiaceae (5), Asteraceae (4sp) that can be used as a learning resource to understand the characteristics of selected family groups.
\end{abstract}

Keywords: Ethnobotany, Medicinal plants, Rejang ethnic, Local wisdom, Learning resources.

\section{INTRODUCTION}

Lifestyle returning to nature which has become a trend nowdays, it has brought people back to use natural ingredients in traditional medicine with medicinal plants [1] [2]. The use of plants as traditional medicine is one of the nation's assets that must be preserved because it is an invaluable cultural and knowledge asset. Likewise in Bengkulu, traditional medical practices which are a cultural heritage have been practiced for a long time and some of them are recorded in ancient manuscripts. Sarwono's [3] study of Traditional Medicine Ulu Manuscripts in the collection of Bengkulu Museum contained 13 ulu script ( $\mathrm{Ka} \mathrm{Ga} \mathrm{Nga)} \mathrm{manuscripts} \mathrm{from}$ the Serawai and Pasemah ethnics. Apart from the Serawai and Pasemah ethnics, Bengkulu Province is quite rich with its original ethnics, namely the Kaur, Pekal, Pasemah, Rejang, Enggano, Muko-muko and Lembak [4] ethnics, living in different ecosystem areas so they have different knowledge about wisdom in using plants in traditional medicine.

According to the World Health Organization (WHO), the use of herbal medicine in the world health agency has reached up to $65 \%$ of the population of developed countries and $80 \%$ of the population of developing countries [5] [6]. In Nepal's Himalayas [7] people use parasitic plants as herbal medicine. Indonesia 
is the world's second largest area of biodiversity wealth, including a rich variety of medicinal plants and thousands of species already used by the community. Various ethnics use plants as ethnomedicine ingredients with unique ingredients and methods of presentation that show high local ethnic knowledge about medicinal plants. One such ethnicity is the Rejang ethnic group in Bengkulu Province.

Rejang ethnic is found dominant in Rejang Lebong Kepahiang Regency and Lebong Regency [8]. According to traditional medicine experts called "smart people". The Rejang ethnic has long developed traditional medicine that they got from their ancestors. His intelligence in medicine was used by the surrounding community, and this tradition has long been developed before formal health services through modern medicine. It's just that this tradition is more often carried out orally than in writing, so the possibility of knowledge information from generation to generation can be reduced. This documenting knowledge is not good enough, therefore it is necessary to do further documentation in the form of oral traditions. Research on medicinal plants of the Rejang ethnic is also still small [8] [9] [10], so it needs to be documented.

Knowledge of medicinal plants is a hereditary national cultural heritage whose inheritance needs attention. This study is also known as Ethnobotany study [11] [12]. The gathering of traditional ethnobotany knowledge is not only important to record endogenous traditions and its rich heritage, but also provides important information for the sustainability of the medicinal plant industry and the discovery of new medicines. The importance of ethnobotany knowledge is integrated into local wisdom-based teaching materialsbecause teaching materials integrated with local potential-based learning effect on learning outcomes [13] [14], increase the ability of scientific processes and foster a positive paradigm [15] [16], increase knowledge students against medicinal plants [17]. The course that discusses about the use of plants is integrated withplant taxonomy. This study aims to determine the diversity of medicinal plants in the traditional medicine of the Rejang ethnic as a learning resource based on local wisdom.

\section{RESEARCH METHODS}

The research was conducted in Teladan village, Batu Panco, Tasik, Air Pikat, Rejang Lebong Regency. The research was conducted by using observation and interviews with traditional healers who were selected as samples and determination. Determination of the people who were selected to be the sample was carried out by purposive sampling, namely smart people/Battara and people know of medicinal plants.
Interviews were conducted to obtain information about the name of the region, the types of plants used as medicine, the use of these medicinal plants in curing diseases [11] [12]. After the interview was carried out, the documentation of the plant shoot was carried out and the collection of medicinal plants was then made for a herbarium. Plant determination to get the Latin name by matching the plant specimen with the determination reference book. Data analysis was carried out descriptively.

\section{RESULTS AND DISCUSSION}

\subsection{Diversity of Rejang Ethnic Medicinal Plants}

From the results of research on the Rejang community in Teladan village, Batu Panco, Tasik, Air Pikat, Rejang Lebong Regency, it found that 101 types of medicinal plants that can treat 90 kinds of diseases and including 50 families. The dominant taxa families with the number of species are Zingiberaceae (8), Euphorbiaceae (7) Achantaceae (6), Fabaceae (6), Solanaceae (5), Lamiaceae (5), Asteraceae (4), Poacea, Myrtaceae, Liliaceae, Amaranthaceae. They have 3 species of each and other 39 families have two and one species. The same dominant family is also found at Mulam people in Guangxi China [18], Fabaceae, Asteraceae, Poaceae and Euphorbiaceae, while in Harighal, Azad Jammu \& Kashmir Pakistan it is dominated by Fabaceae and Asteraceae [19] Zingiberaceae is a family with the dominant species in the Rejang ethnic having nine types of plants in traditional medicine, namely: Alpinia galanga L. / Lengkuas / Lajo, Amomumcompactum, Curcuma longa /kunyit, Curcuma xanthorrhiza / temulawak, Curcuma mango / kunyit puteak, / Kencur / Cekea, Zingiberofficinale Kaempferiagalanga / Jahe, Zingiberauruginosa / temuireng. This family is mostly use in the regions of Malesia and India, especially for medicine and cooking spices [20] [21]. Zingiberaceae is used for baths after childbirth, wounds, appetite enhancer, tonsils, stomach aches, body aches, fever, allergic scabies, tinea versicolor and ringworm, stomach ulcers and flatulence, body odor and dry skin peeling, reduces nausea and vomiting. headaches, treat rheumatism, colds and coughsis

From the eight species in the Zingiberaceae family, the Rejang ethnic mostly uses TemuLawak / Curcuma xanthorrhiza and Jahe / Zingiber officinale. Curcuma xanthorrhiza treats body aches, treats fever, increases appetite, postpartum medication, treats scabies while Zingiber officinale uses it to treat headaches (using ginger rhizome plus coconut oil, then ordered to the head) to treat rheumatism by using ginger rhizome. heated over a fire, pounded, then affixed) and treat colds and coughs by boiling the rhizome is drunk. There are 260 types of medicinal plants for fitness, the ginger plant / Zingiber officinale has the highest number of 
herbs found in 17 ingredients, this fact illustrates that the use of traditional medicines plays an important role in maintaining health [22]. The results of phytochemical screening showed that the simplicia of the ethanol extract of ginger pulp contains phenolic compounds, alkaloids, flavonoids, tannins, monoterpenes, sescepen, quinone, which have analgesic activity [23]. This family is characterized by herbs, leaves distichous, sheaths mostly open plants aromatic, with abundant etherial oil cells; labellum formed from 2 connate staminodes of the inner staminal cycle; two stamens of the outer cycle often developed as small or petaloid staminodes flanking the fertile stamen or adnate to the labellum [24].

The Euphorbiaceae family with eight types of medicinal plants can cure diseases, namely: Tinosporacrispa L. / Brotowali / Cintoali (to increase immunity, relieve fever, treat skin diseases such as itching), Manihot utilissima / Cassava (to relieve rheumatism, fever, wounds to reduce blood loss) Sauropus androgynous L. / Katuk, (facilitate breastfeeding, can be used as a fever medicine and is often used in accelerating wound healing. Jatrophacurcas/jarak pagar (treating toothache, promoting breastfeeding, menstruation, relieving heat, to cure stomach aches), Jatrophatirucalli / broken bones (toothache), Jatropamultifida, betadin (wound, high blood pressure), Euphorbia hirta / patikankebo (scabies / ulcers). In general, the Euphorbiaceae family is used to relieve fever by the Rejang ethnic. This same function also found inthe people of Lake BuyanTamblingan, Bali, which uses Aleuritesmoluccanus (L.) Willd. / Tingkih [25]. Jatrophacurcasis very effective, being used as a heat sink, besidesused in heal wounds. Castor sap in the form of the best healing gel at a concentration of $16 \%$ with the fastest wound healing time of 6 days [26].

Jatropha contains tannins and saponins. Tannins are known can act as an astringent, stop bleeding and prevent infection while healing internal wounds, while saponinscan cleanse and trigger the formation of collagen, a protein that plays a role in wound healing. In addition, $6 \%$ curcain protease or proteolytic enzymes were found in Jatropha sap and can accelerate wound healing with concentrations of $0.5 \%$ and $1.0 \%$ or equivalent to sap with a concentration of $16 \%$ [27].

The Achantaceae family with six species of medicinal plants can cure diseases, namely: Justiciagendarussa/Ganda Deer /Ganuso (Treating headaches), Graptophyllumpictum/ Wungu Leaves/ Red Pudding (treating bruises, ulcers), Ruelliatuberosa / Purple Gold /Purple Trumpets (treating itching, hypertension),

Andrographispaniculata/Sambiloto/Pedeu Leaves (treats malaria, ulcers, scabies and neutralizes venom from wild animals, swollen feet, gout,
Strobilanthescrispus / Keji Beling / KijingBeling (treats constipation, hemorrhoids, kidney stones and pain) waist), Hemigraphisalternata/Pecah Beling (treating wounds, kidney stones and diabetes). Family with characteristics plants not insectivorous, and only occasionally aquatic, placentation various, but not freecentral, corolla mostly 5-lobed and/or more or less strongly irregular, fruit explosively dehiscent, the seeds with enlarged and specialized funiculus that is typically developed into a jaculator, characteristic cystoliths usually present in some epiderma and parenchyma cell, seeds with scanty or no endosperm [24].

In the village of Naga Tasikmalaya, West Java, the Achantaceae family used is Remek Meat (Hemigraphis colorata) containing alkaloids, tannins and polyphenols, flavonoids, monoterpenoids and sesquiterpenoids, triterpenoids, the leaves are used to treat internal diseases, gastric pain, toothache to relieve pain / antiinflammation[28]. Achantaceae species Dicliptera bupleuroides in Pakistan is used for skin infection, a poultice herbal formulation is used for scabies, and Justicia adhanata species for blood purification [29]. Its use is the same as the Graptophyllum pictum type in the Rejang ethnic group. The similarity in use in the family, although different types show a kinship relationship in ethnobotany characters.

The Fabaceae family with six species of medicinal plants can cure diseases, namely: Psophocarpustetragonolobus L. / Kecipir (Increase appetite), Gliricidiamaculata / Gamal (scabies or other skin diseases), Cassia alatal daun Setepeng / Chinese Ketepeng (Treating tinea versicolor, ringworm and diseases other skin), Caesalpineaechinata / kebiul (treating high blood pressure and kidney stones) Mimosa pudica / daughter shame (treating vertigo, smoothing blood), Tamarindus indica / tamarind (cough medicine). This family group is easily identified as legumes. In Yunnan China [30] the Fabaceae family is used for Medicinal dietary plants and its benefits are also to cure diseases, these plants and diseases that cured are Pisum sativum L., (Gastralgia, Parochetus communis (Rheumatism; gastric disorders), Pueraria montana (Reducing phlegm), Sophora davidii (Dysmenorrhea), Styphnolobium japonicum (Clearing liver and improving vision), Vicia faba (Tonifying the spleen; detumescence). The Fabaceae family was also found to have a number of species which were dominant in the village of Penyengat Sungai Apit Siak Riau. The most dominant family in the number of species in this area were in the order of high Rubiaceae (11 species), Zingiberaceae (9 species), Fabaceae (8 species), Myrtaceae (8 species), Phyllantaceae ( 8 species) and Astreaceae (7 species) [31].

The Solanaceae family with six species of medicinal plants can cure diseases, namely: Physalisangulata / Ciplukan / Kecinoak (treat diabetes and itching of the 
skin) Solanumlycopercium/ Tomato (treat acne), Solanum melongena / Eggplant / Telung (Treat itching and treat itching boils) Capsicum frutescens / Cayenne Pepper / Chilimbun (treat dog bites and mild venomous animals). In the Mandailing ethnic of the Solanaceae family, the species Inggir-Inggir / turkey berry leaves (Solanumtorvum) is used for eye medications, poisoning and insect venom [32]. A previous study reported that extract of Inggir-Inggir leaves could inhibit the growth of Staphylococcus aureus [33].

The Lamiaceae family with six species of medicinal plants can cure diseases, namely (5) Orthosiphon aristatus / Cat's Whiskers/ kumis kucing (shed kidney stones and lumbago) Ocimum sanctum / Basil (treats flatulence and nausea) Ocimum tenuiflorum / RukuRuku (treats sprains, inflammation and fever) Peronema canescens / Sungkai (treats itching, bruising, malaria), Plectrantus scutellarioides / Iler / Atei Mileak (treats ear disorders such as congestion). In the Serampas ethnic in Jambi, the Lamiaceae family, the species Ocimum Basilicum / Telasih Hijau isused for fever, accelerated childbirth, Orthosiphon / Sungui kucing are used for lumbago, for malaria the use of Clerodendrum Philippinum / Sekambing [34].

\subsection{Habitus, Plant Organs And Conservation of Medicinal Plants Used by the Rejang Ethnic}

Based on the character of habitus, there are 6 habitats of plant diversity, consisting of trees (19 species), shrubs (26), shrubs (4 species), herbs (46 species), lianas (6 species). From this grouping, the most dominant herbal habitats were 46 species. The classification of plants based on Habitus is the oldest classification pioneered by Theophrastus [35] and until now this character is still used in describing plants in the plant taxonomy subject matter which is placed at the beginning of the description of a plant. for example the description of Solanum nigrum: erect herb, up to $1.5 \mathrm{~m}$ high and 3-16 cm long, 2-12 cm wide flowers with bowed buni, white purple flowers, ripe purple or black purple berna, diameter 8-10 [36].

From the 101 medicinal plant species belonging to 50 families found to be medicinal, it is known that almost all of the organs of the plant are used, starting from roots, rhizomes, stems, leaves, flowers, fruits, seeds, gums. Leaf organs have the most widely used organs, (56 plant species) as well as those found in other regions such as the Mandailing ethnic group [32], the reason leaves are widely used because they are easy to process and have many chemical compounds [37]. For some medicinal plant species, the entire plant organs are used, for example, the species Amaranthusspinosus / spinach thorn, Celosia argentae / arum milek, Celosia cristata. Besides that, theorgansused are only for the leaves, the stems, or in combination between stems and leaves, fruit and leaves. With the variety of chemical content inthese organs, it is possible to complement each other and accelerate the healing of diseases. For example, from the phytochemical analysis of the leaf and stem organs of star fruit (Averhoa bilimbi), the leaves contain streroids and flavonoids while the stems contain saponins and triterpenoids [38]. Then,in conservation aspect, the use of leaves does not damage plants because plants generally grow to have many leaves.

Conservation is an effort made by humans to protect or preserve various things that are considered important for human life. In terms of protecting medicinal plants, the Rejang ethnic group has cultivated plants in their yards or gardens. Although,it is not only specifically for treatment, there are other functions such as ornamental plants (Allamandacatharthica, Jatropomultifidal betadin), vegetable plants (Manihot utilissimal cassava, Sauropus androgynus / katuk), and specifically for medicinal plants such as red pudding / Gratopyhllum. pictum, Anrederacordifolia / binahong). Other functions of medicinal plants are for hedgerows (Jatropha curcas), kitchen spices (Ocimum tenuiflorum / ruku-ruku, Cymbopogon citratus / lemongrass. Besides medicinal plants $(92 \%)$ it also comes from weeds or wild plants, there are 8 species (8\%) such as Amaranthus spinosus, bandotan / Ageratum gonizoides, Patikan kebo / Euphorbia hirta, Meniran / Phyllantus niruri. The potential of wild plants as medicinal plants is very much. types of diseases, [39], for example fever, cough with phlegm, hemorrhoids, hypatitis, vomiting of blood, urine, etc. The results obtained in the Rejang ethnic were very low because the research was not focused on wild plants. many are less well known for its medicinal potential [39].

\subsection{Types of diseases found in the Serawai ethnic group}

From the results of field observations in the Rejang ethnic in this research area, 90 types of diseases can be traditionally treated using 101 species of medicinal plants. 1 type of disease can be treated with various species andotherwise, 1 plant species can treat various kinds of diseases. Diseases with some of the dominant medicinal plants are as follows: fever (15 species), wounds (12 species) hypertension (10 species), bruises, ulcers (7 species) itching, malaria, diabetes, ulcers (6 species), cough, scabies (5 species), constipation, kidney stones, asthma, stomachache, ringworm, tineaversicolor, hair fertilizers, rheumatism (4 species), headache, menstrual pain, joint pain, toothache, backache, diarrhea, menstrual flow (3 species) gout, hemorrhoids, urinating blood, difficulty urinating, worms, fever in children, scabies, sprains, hepatitis, tonsils, after birth, lack of appetite, colds, vertigo (2 species) and others such as neutralizing can, vaginal discharge, memory and others (1 species). 
Fever in the Rejang ethnic can be treated by using 15 plant species, similar research results were also found in the Malays in Sambas that from 233 plant species, there are 103 groups of diseases treated in this ethnic, fever is one of the groups with the highest score using medicinal plants together with utilization for antibiotics, smallpox, and so forth [40]. Many types of plants that have been invested can treat fever because it may be that the local people are often attacked by this disease. This is probablydue to the notoriously high cold weather and high rainfall in this area that making people susceptible to fever. So, they are looking for alternative treatments by using plants around them. Types of plants to treat fever are Jatropha curcas, Hibiscus rosa sinensis, Imperata cylindrica, Cocos nucifera, Kalanchoe pinata, Allamanda cathartica, Colocasia esculenta, Tinospora crispa, Manihot utilissima, Sauropus androgynous, Peperomia pellucida, Imperata cytrifolia, Sacharylinarum, Citrus aurintifolia, Tamarindus indica, Hibiscus rosa-sinensis. Treatment is done by drinking, eating, boiling and drinking, steam baths, compresses, stick to the forehead. Plants that can reduce fever include antipyretic plants [41].

The medicine are able to reduce the fever back to normal temperature work by inhibiting the enzyme cyclo oxygenase- 2 in the central nervous system to prevent the conversion of arachidonic acid to prostaglandins which are fever mediators [42]. These antipyretic plants generally have an activity that inhibits the cyclooxygenase (COX) enzyme which plays a prostaglandin role so that fever does not occur [43].

One of the interesting things, among others, the Rejang ethnic here is the use of pepper / Piper ningrum. This plant, apart from being a superior commodity of the Rejang community, is also used for medicine, namely reducing odor in the armpits (mix pepper powder with whiting and oil, apply it on the armpits) treat coughs (mix pepper powder with soy sauce then drink), nasal congestion (mix pepper powder with hot water then inhale). According to Pundir and Pranay [44], Black pepper is a plant that has been shown to have antibacterial activity. The ethanol extract of black pepper fruit has antibacterial activity against grampositive bacteria Staphylococcus aureus with an inhibitory power of $>10 \mathrm{~mm}$. The antibacterial activity of black pepper fruit against $\mathrm{S}$. aureus is caused by the presence of piperine content.

\subsection{The diversity of medicinal plants of the Rejang Ethnic as a learning resource based on local wisdom}

Documenting medicinal plants is not only useful for community needs, but also useful for the world of education, namely as a source of learning biology for students and university students. Learning is a process of interaction between students and educators and learning resources in a learning environment. Students need to be prepared to be critical, creative and have an awareness of the importance of preserving environmental functions for the needs of their generations and future generations in managing living natural resources through education. Education is an effort to prepare students to have high quality intellectual, emotional, spiritual and social abilities [45] [46].

A total of 101 species diversity of medicinal plants and 50 levels of family taxon found to treat 90 diseases in the community that is the knowledge of the local wisdom of the Rejang ethnic. Can be used as a learning resource that needs to be developed for students, on the concept of taxonomic joints and plant diversity at taxon species and family levels and their benefits. The arrangement of teaching materials with examples of plants based on local wisdom as a learning resource makes learning more meaningful and is contextualbased learning as an effort to increase student interest in Plant Taxonomy in Higher Education [47]. Contextualbased learning needs to be developed through projects and teaching materials based on local wisdom.

Ethnobotany studies have the potential to be developed or integrated in the fields of education, art, culture, health, food, and so on, so that it indirectly contributes to development in line with the development of science and technology while still preserving our local cultural wisdom [48]. This is in line with the recommendations in the guidelines for composing higher education curricula to support the Merdeka Belajar Kampus Merdeka [49] curriculum, that the curriculum must be able to pass on culture from one generation to the next amid the exposure to the influence of globalization which erodes the existence of local cultures too. The curriculum must be able to release learners from the confines of their own rigid cultural barrier and are not aware of their own cultural weaknesses. In the present context, students are expected to be able to have cultural agility which is considered a mega competency that must be possessed by professional candidates in the 21 st century by mastering three competencies, namely: cultural minimization, cultural adaptation, cultural culture.

Medicine is a culture that has been passed down from generation to generation. The cultural wisdom of traditional medical knowledge should be recognized by future generations. But in fact, this is not the case, the results of a preliminary study conducted by Zukmadini et al. [17] at the high school level (SMA) in Bengkulu City and Bengkulu Regency, it was found that the level of knowledge of senior high school students' local wisdom on medicinal plants was still very low, where 75\% students do not know the types of plants that have the potential to treat disease, $50 \%$ of students do not know the potential of ethnic local wisdom in the use of medicinal plants in Bengkulu Province, $75 \%$ of students never use plants to treat diseases and $95 \%$ of students do 
not know how to use plants to treat a disease. Furthermore, after the implementation of local wisdombased teaching materials in these students, there was an increase in local wisdom knowledge about medicinal plants by around $30 \%$, a significant result between before and after the use of locally based teaching materials.

From generation to generation, traditional communities develop local wisdom about non-formal knowledge which is useful for the survival and development of their culture. The development of local wisdom serves to document and explain the complex relationship between culture and plant use with the main focus on how plants are used, managed as food, medicine, religious practices, cosmetics, dyes, textiles, clothing, rituals and social life.

\section{CONCLUSION}

From the survey research, the results showed that medicinal plants used in the traditional treatment of the Rejang Ethnic in several locations in Rejang Lebong Regency, 101 species of medicinal plants were found in the traditional treatment process of the Rejang Ethnic which can treat 90 types of diseases. Diseases such as fever, skin disease, gastritis, cancer, infertility, wounds, and others. Plant species that are widely used for fever (15 species), wounds (12 species) hypertension (10 species), bruises, ulcers (7 species) itching, malaria, diabetes, magh (6 species), cough, scabies (5 species) ), constipation, kidney stones, asthma, stomachache, ringworm, tinea versicolor, hair fertilizers, rheumatism (4 species). The dominant taxa families with the number of species are: Zingiberaceae (8), Euphorbiaceae (7) Achantaceae (6), Fabaceae (6), Solanaceae (5), Lamiaceae (5), Asteraceae (4), Poacea, Myrtaceae, Liliaceae, Amaranthaceae. 3 species each. 39 Other families have and one species.

\section{ACKNOWLEDGMENTS}

We would like to thank the key informants and various parties who have assisted in the research and writing of this paper so that it can be done. This research was conducted with the PPKP FKIP UNIB 2020 grant, number 9200/UN30.7/HK/2020.

\section{REFERENCES}

[1] S. Hidayat, Keberadaan Dan Pemanfaatan Tumbuhan Obat Langka Di Wilayah Bogor Dan Sekitarnya, Media Konservasi, vol. 17 (1), 2012, pp $33-38$.

[2] J. Sambara, Y. Ni Nyoman, Y.E Maria, , Pemanfaatan Tanaman Obat tradisional Oleh Masyarakat Kelurahan Merdeka Kecamatan Kupang Timur, Jurnal Info Kesehatan, vol. 14 (1), 2016.
[3] S.N. Sarwono, Rahayu, Naskah Hulu Pengobatan Tradisionil Koleksi Museum Negeri Bengkulu. Jurnal Inovasi. Jurnal Penelitian dan Pengembangan Inovasi, vol. 2 (1), 2016.

[4] M.J. Melalatoa, Ensiklopedi Suku Bangsa Di Indonesia. Depdikbud RI, 1995.

[5] B. Purwanto, Herbal dan Keperawatan Komplementer, Nuha Medika, Yogyakarta.

[6] B. Anas, H.B. Santoso, Tumbuhan Liar Berkhasiat Obat, Fordo Press, Bogor, 2016.

[7] O’Neill, A. Robert, S.K Rana, An Ethnobotanical Analysis of Parasitic Plants (Parajibi) in the Nepal Himalaya, Journal of Ethnobiology and Ethnomedicine, vol. 12 (14), 2016, DOI: https://10.1186/s13002-016-0086-y

[8] N. Betti, Studi Etnobotani Suku Rejang dan Implementasi Pendekatan Jelajah Alam Sekitar (JAS) Dalam Pembelajaran Biologi, Tesis Program Pascaarjana Pendidikan IPA FKIP Universitas Bengkulu, 2011.

[9] Windayani, Kasrina, I. Ansori, Pengembangan Buku Saku Berdasarkan Hasil Eksplorasi Tanaman Obat Suku Rejang Kecamatan Merigi, Diklabio: Jurnal Pendidikan dan Pembelajaran Biologi, vol 2(1), 2018, pp 51-57.

[10] S. Nugeraha, Yennita, A.P. Yani, Pengembangan Lembar Kerja Peserta Didik Berdasarkan Identifikasi Tumbuhan Obat Desa Cahaya Negeri Kabupaten Rejang Lebong, Diklabio: Jurnal Pendidikan Dan PembelajaranBiologi, vol 4 (1), 2020, pp 10-16. DOI: https://doi.org/10.33369/diklabio.4.1.10-16

[11] G.J. Martin, Ethnobotany: a methods manual, Chapman \& Hall, London, 1995, pp 1-268.

[12] Hakim, Luchman, Etnobotani dan Manajemen Kebun Pekarangan Rumah :Ketahanan pangan, kesehatan dan agrowisata, Selaras, Malang, 2014.

[13] K. Santiningtyas, A.P.B. Prasetyo, B. Priyono, Pengaruh Outdoor Learning Berbasis Inkuiri Terhadap Hasil Belajar Materi Ekosistem, Unnes Journal of Biology Education, vol 1 (2), 2012, pp 91-98.

[14] M. Muthmainah, N. Nurmiyati, S. Dwiastuti, Pengaruh Penggunaan Modul Berbasis Potensi Lokal pada Topik Ekosistem terhadap Pemahaman Konsep dan Sikap Peduli Lingkungan Siswa Kelas $\mathrm{X}$, Proceeding Biology Education Conference, vol 13(1), 2016, pp 293-298.

[15] A, Patricia, Carrying Plant Knowledge Forward in USA. In. Innovative Strategies for Teaching in the 
Plant Sciences. Ed, Cassandra L. Quave, Departement of Dermatology and Center for Study of Human Health Emory University School of Medicine, Atlanta, Georgia, USA, 2014. DOI: https://10.1007/978-1-4939-0422-8

[16] B. Karyadi, A. Ruyani, A. Susanta, S. Dasir, Pembelajaran Sains Berbasis Kearifan pada Sekolah Menengah Pertama di Wilayah Bengkulu Selatan, Proseding Seminar Nasional Pendidikan Sains (SNPS), Surakarta, 2016.

[17] A.Y. Zukmadini, K Kasrina, D Jumiarni, S. Rochman, Pocketbook based on local wisdom and its effectivity in improving students' knowledge on the utilization of traditional medicine plants, Biosfer: Jurnal Pendidikan Biologi, vol 13 (1), 2020, pp 59-74. DOI: https://doi.org/10.21009/biosferjpb.v13n1.59-74

[18] H. Renchuan, C. Lin, W. Xu, Y. Liu, C. Long, Ethnobotanical study on medicinal plants used by Mulam people in Guangxi, China, Journal of Ethnobiology and Ethnomedicine, vol 16 (40), 2020, DOI: https://doi.org/10.1186/s13002-020$00387-\mathrm{z}$

[19] Amjad, M. Shoaib, U. Zahoo, W. Rainer, Bussmann, M. Altaf, S. M. H. Gardazi, A.M Abbasi, Ethnobotanical survey of the medicinal flora of Harighal, Azad Jammu \& Kashmir, Pakistan 2020. Journal of Ethnobiology and Ethnomedicine, vol 16 (65), 2020, DOI https://doi.org/10.1186/s13002-020-00417-w

[20] A. Auliani, Fitmawati, N. Sofyanti, Studi etnobotani familizingi beraceae dalam kehidupan masyarakat lokal di Kecamatan Siak Hulu Kabupaten Kampar. JOM FMIPA, vol 1(2), 2014, pp 526-533.

[21] W. Sujarwo, A.P. Keim, V. Savo, P.M. Guarrera, G. Caneva. 2015. Ethnobotanical study of Loloh: Traditional herbal drinks from Bali (Indonesia). Journal of Ethnopharmacology, vol 169, 2015, pp $34-48$.

[22] A. Saikhu, Potensi Tanaman Obat Sebagai Immunomodulator Dan Antiviral, Balai Besar Penelitian dan Pengembangan Tanaman Obat dan Obat Tradisional, Makalah WEBINAR ICTS (Innovasi Centre For Tropical Science ), 2020.

[23] Y. Febrian, H. Riasari, W. Winingsih, D. L. Aulifa, A. Permatasari, The Potential Use of Red Ginger (Zingiber officinale Roscoe) Dregs as Analgesic, Journal of Pharmaceutical Science and Technology Journal, vol 1 (1), 2018, pp 57-64.
[24] Q. Arthur, An Integrated system of classification. Columbia University Press, Columbia, 1981.

[25] Oktavia, G, A. Esa, I.D.P Darma., W. Sujarwo, Studi Etnobotani Tumbuhan Obat Di Kawasan Sekitar Danau Buyan-Tamblingan, Bali, Buletin Kebun Raya, vol 20 (1), 2017.

[26] T.L. Hajiriah, P.K Intan, Uji Efektifitas Getah Jarak Pagar (Jatropha Curcas) Sebagai Obat Pengganti Antiseptik Kimia, Jurnal Hasil Penelitian dan Kajian Kepustakaan di Bidang Pendidikan, Pengajaran dan Pembelajaran, vol 5 (20), 2019, pp 141-148.

[27] S.K. Dutta, Curcain - a Protease Isolated from the Latex of Jathrophacurcas Linn. India, Departement of Pharmaceutical Technology, Jadavpur University, 2010.

[28] I. Rahmiyani, M.S. Mulyono, R. Mardian, Inventarisasi Dan Skrining Fitokimia Tumbuhan Obat Berkhasiat Anti Inflamasi Yang Digunakan Oleh Masyarakat, Jurnal Kesehatan Bakti Tunas Husada, vol 13 (1), 2015.

[29] Khan, Imran, M. Naser, A. Elsalam, H Fouad, A. Tariq, Application of Ethnobotanical Indices on the Use of Traditional Medicines against Common Diseases Evidence-Based Complementary and Alternative Medicine, 2014, DOI: https://dx.doi.org/10.1155/2014/635371

[30] S. Jingxian, Y. Xiong, Y.L.Q. Yang, Y.Chen, M. Jiang, Y. Li, H. Li, Z. Bi, X. Huang, S. Lu, Medicinal dietary plants of the Yi in Mile, Yunnan, China, Journal of Ethnobiology and Ethnomedicine,vol 16 (48), 2020. DOI: https://doi.org/10.1186/s13002-020-00400-5

[31] R.D. Utami, E.A.M. Zuhud, A. Hikmat. Etnobotani Dan Potensi Tumbuhan Obat Masyarakat Etnik Anak Rawa Kampung Penyengat Sungai Apit Siak Riau, Media Konservasi vol. 24 (1), 2019, pp 40-51.

[32] A. Nasution, T. Chikmawati, E.B Walujo, E.A.M Zuhud, Ethnobotany Of Mandailing ethnic In Batang Gadis National Park. The Journal Of Tropical Life Science, vol. 8 (1), 2018, pp 48-54. DOI: https://10.11594/jtls.08.01.09

[33] Elmitra, Uji daya hambat ekstrak etanol daun takokak (Solanumtorvum Swartz) terhadap bakteri Stapylococcusaureus, Jurnal Ilmiah Pharmacy, vol 2, 2015, pp 24-29.

[34] B. Hariyadi, T. Ticktin, Uras: Medicinal And Ritual Plants Of Serampas, Jambi Indonesia, Ethnobotany Research \& Applications, vol 10, 2012, pp 133-149. 
[35] S.S. Tjitrosoediro, C. Tatik, S.A. Nunik, R.D, Nina, Taksonomi Tumbuhan Tinggi, Penerbit Universitas Terbuka, Kemenristekdikti, Banten., Indonesia, 2019.

[36] Steenis, Flora Pegunungan Jawa, Pusat Penelitian Biologi LIPI, Bogor, Indonesia), 2020.

[37] Y.R. Irawan, Fitmawati, Herman, Pengetahuan tumbuhan obat dukun Sakai Desa Sebangar Duri Tiga Belas dan Desa Kesumbo Ampai Duri Kabupaten Bengkalis, Bi-osaintifika: Journal of Biology and Biology Education vol 5 (1), 2013, pp 30-35.

DOI: https://10.15294/biosaintifika.v5i1.2571

[38] Kasrina, Pemanfaatan Tumbuhan Obat Tradisional Oleh Masyarakat Etnis Serawai Berbasis Naskah Kuno Ka Ga Nga Di Desa Kampai Talo Kabupaten Bengkulu Selatan, Prosiding Seminar Nasional Dan Rapat Tahunan Bidang MIPA, UNTAN. Pontianak, 2015.

[39] T. Kartika, Potensi Tumbuhan Liar Berkhasiat Obat Di Sekitar Pekarangan Kelurahan Silaberanti Kecamatan Silaberanti, Sainmatika vol 14 (2), 2017, pp 89-99.

[40] R.N. Pranaka, F. Yusro, I. Budiastutik . Pemanfaatan Tanaman Obat Oleh Masyarakat Suku Melayu Di Kabupaten Sambas . Jurnal Tumbuhan Obat Indonesia, vol 13 (1), 2020, pp 124.

[41] A. Suproborini, M.S.D. Laksana, D.F. Yudiantoro Ethnobotany Antipyretic Plants Peoples In Dusun Mesuboto Jatiroto Wonogiri Central Java, Journal of Pharmaceutical Science and Medical Research, vol 1 (1), 2018.

[42] D.I. Husori, Antipiretika Dan Analgetika, Departemen Farmakologi Farmasi, Fakultas Farmasi, USU, 2016.
[43] B. Jethani, R.K. Sharma, M. Raipuria, H. Jai, Antipyretic activity ofaqueous and alcoholic extracts ofnoni on yeast induced pyrexia in rats. Int J Pharm Sci Res, vol 2 (7), 2011.

[44] R.K. Pundir, P. Jain, Comparative Studies on The Antimicrobial Activity of Black Pepper (Piper nigrum) and Tumeric (Curcuma longa) Extracts, International Journal of Applied Biology and Pharmaceutical Technology, vol 1 (2), 2010, pp 491-500.

[45] Nurrohman, E. A. Rahardjanto, S. Wahyuni, Keanekaragaman Makrofauna Tanah di Kawasan Perkebunan Coklat (Theobroma cacao L) sebagai Bioindikator Kesuburan Tanah dan Sumber Belajar Biologi, Jurnal Pendidikan Biologi Indonesia, vol 1 (2), 2015, pp 197-208.

[46] B. Fatmawati, Pembelajaran Berbasis Proyek untuk meningkatkan Ketrampilan Berpikir Kreatif Mahasiswa, Jurnal Pengajaran MIPA, vol 16 (2), 2011, pp 85-92.

[47] M. Saptasari, Pembelajaran Berbasis Kontekstual Sebagai Upaya Peningkatan Minat Mahasiswa Pada Taksonomi Tumbuhan Di PerguruanTingg, Jurnal Pendidikan dan Pembelajaran, vol 19 (2), 2012.

[47] I.K. Surata, I.W. Gata, Pengembangan Buku Ajar Botani Tumbuhan Tinggi berbasis Etnobotani Masyarakat Hindu Bali, Seminar Nasional Riset Inovatif III, 2015.

[48] Direktur Jendral Pendidikan Tinggi, Panduan Penyusunan Kurikulum Merdeka Pendidikan Tinggi di Era Industri 4.0 Untuk Mendukung Merdeka Belajar Kampus Merdeka, Kementrian Pendidikan dan Kebudayaan, Jakarta, Indonesia, 2020.

[49] K. Mesfin, G. Tekle, T. Tesfay, Ethnobotanical Study of Traditional Medicinal Plants Used by Indigenous People of Gemad District, Northern Ethiopia, Journal of Medicinal Plants Studies, vol 1 (4), 2013, pp 32-37. 